\title{
Attributes of design for construction waste minimization: A case study of waste- to-energy project
}

\begin{abstract}
Despite the consensus that waste efficient design is important for reducing waste generated by construction and demolition activities, design strategies for actual waste mitigation remain unclear. In addition, decisive roles required of designers in designing out waste remains inadequately addressed. As such, this study aims to map out attributes of waste effective design and design documents. Drawing on series of semi-structured focus group discussions with experts from the UK leading design and construction companies, this paper employs qualitative approach to explore design and design document qualities for waste efficient construction projects.
\end{abstract}

The study suggests that for a design to assist in reducing construction and demolition waste, it needs to fulfil five key requisites, while its documentation is expected to fulfil four key requisites. A waste efficient design would incorporate standardization and dimensional coordination, employ principles in modern methods of construction, provides measures for spatial and components flexibility, make provisions for end of life deconstruction and employs techniques in BIM for design coordination. Waste efficient design documentation, on the other hand, is characterised by completeness and clarity, certainty and timeliness, freedom from error, and incorporation of set of plans and schedules that are waste militating. A validation of these findings in a case study of waste-to-energy project confirmed that the strategies are essential to preventing construction waste. Measures through which design and design documents could achieve the identified waste effective attributes are highlighted and discussed.

Findings of this study could assist in understanding a set of measures that should be taken at project planning and design stages in order to mitigate waste intensiveness of the construction industry. It would as well assist designers in understanding a set of attributes that must be possessed by design and design documents in order to design out construction waste.

Keywords: Design out waste; Energy-to-Waste; Design documents; Deconstruction; Buildability; Construction waste. 


\section{Introduction}

Construction industry has been a main target for the global sustainability agenda, as it consumes large portion of materials taken from nature and generates largest proportion of waste to landfill (Paine and Dhir, 2010; Anderson et al., 2003). For instance, a UK report of waste generated per industry shows that while construction industry contributes $44 \%$ of waste in landfill, commercial activities generates as low as $14 \%$ and domestic waste contributes only 13\% (DEFRA, 2013). This huge proportion of construction waste has prompted various legislative and fiscal provisions as well as substantial research efforts, which seeks to unravel both causes and strategies for mitigating construction waste. Despite these, waste generated by construction activities is continuously increasing, irrespective of decrease in those generated by other activities (Ajayi et al., 2015a). Albeit this conundrum, existing literatures have consensually established that design stage is very decisive in reducing waste generated by construction and demolition activities, thereby suggesting a way forward in waste mitigation efforts (cf. Faniran and Caban, 1998; Osmani, 2012; Yuan, 2013; Formoso et al., 2008). For instance, Innes (2004) argued that about a third of construction waste is design induced.

Notwithstanding this understanding, waste related studies have majorly concentrated on construction stage of project delivery (cf. Al-Hajj and Hamani, 2011; Begum et al., 2007; Cha et al., 2009), while waste management efforts are largely made during construction activities, when it is almost late to prevent waste occurrence. This set of studies and practices have only resulted in such strategies as waste reduction, reuse, recycling/recovery and landfilling, which have negative environmental impacts, coupled with substantial financial implications (Saraiva et al., 2012; Benjamin, 2010; Chong and Hermreck, 2011). In addition, few studies addressing design stages have also failed to point out the decisive actions needed to be taken at the design stage in order for it to assist in waste reduction. Otherwise, most of the studies have only arrived at the conclusion that design stage and designers are important in waste preventing activities; while roles needed to be played by the designers remain unaddressed. The strategies through which design could result in waste efficient projects are also subjects of scattered findings across literatures, requiring a focussed study on the concept. This represents a gap in knowledge, which this study aims to fill.

In addition to the foregoing, reworks and its subsequent waste generation has been closely linked to poor documentation of designs (Tribelsky and Sacks, 2011; Thomas et al., 2004). For instance, a 
comprehensive analysis of design document quality (DQI) suggests that poor design document is a major cause of construction reworks (Andi and Minato, 2003). Similarly, a study by Udawatta et al. (2015) identified proper design documentation as a key strategy for mitigating waste generated by construction activities. However, while these sets of studies have consistently pointed out the relationship between waste and documentation of design, strategies for improving waste efficiency of design documents remains unaddressed. Thus, there is need to understand how design and its document could be properly channelled to enhance construction waste minimization.

The overall aim of the study is to explore the attributes of design and design documents for waste efficient construction projects. The study seeks to develop a set of design and its management strategies capable of reducing waste during construction activities. In order to achieve this aim, the study would fulfil the following objectives.

1. To explore and understand attributes and quality of waste efficient design.

2. To determine design document qualities capable of reducing waste generated by construction activities.

3. To develop a design and its documentation strategies for engendering waste efficient construction projects.

4. To evaluate and validate findings of the study, using case study of a renewable energy project.

Because of epistemological understanding that a poorly conceptualised phenomenon could be well developed by suspending all preconditions (Van Manen, 1990), this study employs interpretive approach as its methodological framework. The approach avail the study an opportunity to carry out an in-depth exploration of waste efficient design and its documentation related criteria through focus group discussions.

The paper is structured as followed. The second section of the paper gives an overview of the construction and its waste management process. The third section presents the methodological approach to the study including data collection and analytic procedures. The fourth section presents the thematic data analytical processes as well as the findings of the study. Case study of renewable energy project that validates findings of this study is presented in section five. This is followed by report and discussion of the findings and its practical implications, after which the study is culminated with a summary of the identified issues. Findings of this study is invaluable to designers 
and design firms seeking to design out waste. It will also assist other consortium members to understand areas needed to be strengthened in a bid to reduce waste generated by construction activities.

\section{Construction and its Waste Management}

Construction industry contributes significant portion of the global economy and employs large population across the globe. It accounts for $13 \%$ of the global economy and contributes annual amount of $\$ 12$ trillion, which is projected to reach $\$ 15$ trillion in 2025 , according to a year 2013 analysis by Global Construction Perspectives (GCP, 2013). As at the year 2008, the UK construction industry accounts for $8 \%$ of Gross Domestic Products (GDP), generates employment for over three million workers and contributes annual value of over £100billion (HM Government, 2008). However, the industry is highly fragmented as it seeks to meet demand of its customers within limited budget, resources and time frame. As such, a typical project involves several numbers of drawings and different professional activities, whose successful coordination is not only important for waste minimization, but also for completing the project within budget, expected time, and to the desired quality. This significantly contributes to the waste intensive nature of the industry, making it contributing largest proportion of waste to landfill.

Irrespective of the party responsible for its causes, construction waste affects entire project cost and put heavy burden on the environment. As such, apart from environmental sustainability, reduced resource excavation and prevention of several environmental hazards as likely results of waste reduction (Yuan, 2013; Anderson et al, 2004), proper waste minimization technique has considerable economic benefits. Costs associated with waste include cost of materials purchased, cost of storage, removal, transportation and, eventually, the cost of waste disposal and associated penalties (Coventry and Guthrie, 1998). These series of cost is usually underestimated in terms of disposal charges and penalties, making the financial cost of waste usually understated. A study by the UK Building Research Establishment (BRE, 2003) suggests that successful reduction of UK's construction waste by $5 \%$ could result in savings up to $£ 130$ million. As nations are now running out of landfill sites (Poon, 2007), it is clear that pieces of land voted for landfill also contributes considerable loss.

Based on these series of financial and environmental issues associated with waste, and notably as a response to Kyoto protocol, significant government legislative and fiscal policies have been made 
towards diverting waste from landfill sites. In the UK for instance, landfill tax of $£ 82.60$ is being imposed per unit tonnage of waste disposed and aggregate tax of $£ 2$ is payable per tonnage of virgin aggregate used. Similarly, designs and construction activities are appraised for sustainability using BREEAM and other assessment tools, while the repealed site waste management regulation compel SWMP on every project above $£ 300,000$ (HM Government, 2008). These set of fiscal and legislative provisions have significantly improved the way construction waste is managed (Osmani, 2012) by inculcating waste preventive, reuse and recycling habits in construction professionals.

Corroboratively, various efforts have been made by researchers who employed different methodological tactics in studying cutting-edge approaches to waste management. With the help of industry experts, a set of studies (e.g Tam et al., 2005; Treolar et al., 2003; Formoso et al., 2002; Lau et al., 2008) used case studies of construction projects to identify waste efficient practices. Others (e.g. Al-Hajj and Hamani, 2011; Osmani et al., 2008; Yuan, 2013, Begum et al., 2007; Wang et al., 2014; Oyedele et al., 2013; Faniran and Caban, 1998) surveyed practitioners' opinions towards understanding waste causative factors and effective mitigation practices. These set of studies have furnished the industry with series of waste management measures that could be taken during construction activities. However, little has been achieved in terms of what measures should be taken to enhance waste minimization through design activities. In addition, studies have only pointed out that design document

Notwithstanding this oversight, the cause and effect within the stages of project lifecycle are so much interrelated that mistakes made in earlier stage would affect the subsequent ones (Sterman, 1992; Oyedele and Tham, 2007). Whilst designers usually claim that their activities has little to do with waste, as it occurs onsite (Osmani et al., 2008), it has been reasonably proved that design and schedule are major activities that eventually result in waste (Faniran and Caban, 1998; Love et al., 2008). In addition, studies have also suggested that reworks and subsequent waste generation is usually induced by errors in design document (Love et al., 2008). This suggests that holistic waste management effort would not only consider all stages of project lifecycle, significant attention must be given to the design stage, where most waste reductive measures could be taken. It is as well important that adequate attention be given to design document in order for it to enhance waste minimization in construction projects (Udawatta et al., 2015). 


\section{Methodology}

Notwithstanding the consensus that construction waste could be adequately minimized through design activities, design strategies capable of engendering low waste projects remains inadequately unexplored. In order to map out design strategies for waste mitigation, this study employs focus group discussion as a result of its epistemological and methodological standings. From epistemological point of view, phenomenological approach is suitable when a researcher seek to have an in-depth exploration of a poorly understood or widely neglected phenomenon (Holloway and Wheeler, 1996). This research approach avails an opportunity to interpret the meaning of experience as lived by the research participants in order to gain fresh perspectives (Creswell, 2007). The epistemological approach will therefore assist in getting first-hand information from industry practitioners (Jasper, 1994), thereby mapping out design strategies for waste mitigation. In line with illustrated procedure for phenomenological research (Moustakas, 1994), the researchers' experience were bracketed out in order to collect data from different participants who have adequate knowledge and experience of the phenomenon.

Methodologically, focus group discussions allows a detail exploration of intersubjective opinions among the participants (Wimpenny and Gass, 2000). It allows the participants to build on each other's opinions throughout the course of encounter (Kvale, 1996). In this case, this data collection technique is preferred to quantitative approach, as it allows exploration of new concepts rather than limiting the participants to a set of factors, which might not be exhaustive enough. This is generally in line with phenomenological perspective, which allows the use of in-depth interview or focus group interviews with multiple participants (Creswell, 2013). In all, the study involved four focus group discussions with designers, design managers, waste managers/lean practitioners and contractors/project managers. The participants have their years of experience ranging from seven to 21 years, and they are from various design and construction firms ranging from small to large organisations. The participants have been involved in project coordination in the last five years and they are employees of firms involved in design and/or construction of building projects over the years. A total of 24 information-rich experts were involved in the study. This is in line with a general recommendation that a phenomenological research requires between five and 20 participants (Polkinghorne, 1989). In addition to two members of the research team who served as moderators, Table 1 presents the number of research participants in each of the focus group discussions. 
Table - 1: Overview of the focus group discussions and the participants

\begin{tabular}{|c|c|c|c|c|}
\hline$F G$ & $\begin{array}{l}\text { Categories of the } \\
\text { Participants }\end{array}$ & Main Focus of the discussions & $\begin{array}{l}\text { No of } \\
\text { experts }\end{array}$ & $\begin{array}{l}\text { Years of } \\
\text { experience }\end{array}$ \\
\hline 1 & $\begin{array}{l}\text { Architects and } \\
\text { Design Managers }\end{array}$ & $\begin{array}{l}\text { - Designers approaches for designing out waste } \\
\text { - Design management approach to prevent waste }\end{array}$ & 7 & $7-18$ \\
\hline 2 & $\begin{array}{l}\text { Lean practitioners/ } \\
\text { Waste Managers }\end{array}$ & $\begin{array}{l}\text { - Lean thinking in design } \\
\text { - Design activities that usually result into waste }\end{array}$ & 6 & $7-20$ \\
\hline 3 & $\begin{array}{l}\text { Construction Project } \\
\text { Managers }\end{array}$ & $\begin{array}{l}\text { - Design activities that usually result into waste } \\
\text { - Design strategies for waste mitigation }\end{array}$ & 6 & $10-19$ \\
\hline 4 & $\begin{array}{l}\text { Civil and structural } \\
\text { engineers }\end{array}$ & $\begin{array}{l}\text { - Design activities that usually result into waste } \\
\text { - Design approach to prevent construction waste }\end{array}$ & 5 & $9-21$ \\
\hline \multicolumn{3}{|r|}{${ }^{2}$} & 24 & \\
\hline
\end{tabular}

The groups of participants were selected based on critical sampling, as there is need for each of the architects, civil/structural engineers, site waste managers and construction project managers to be represented. This sampling technique was used based on assertions that it enhances applicability of findings to other cases (Creswell, 1998). Both the designers who are at the performing end, and the other teams at the receiving end were all involved in the focus group discussions. This is important, as evidence shows that while contractors believed that designers are responsible for most waste generation, designers opined that waste is site induced and its mitigation is contractors' responsibility (Osmani et al., 2008; Oyedele et al., 2014). Therefore, involvement of the two groups allows findings of the study to be built on intersubjective opinions from the two key stakeholders.

Nonetheless, convenient sampling technique was employing in selecting individual participants, through researchers' network of contact within the construction industry. This approach avail the researchers an opportunity to select participants that are deemed information-rich for the study (Merriam, 1998). Effort was however made to ensure that conveniently selected participants are within the professions required for the study. Other studies that have employed this sampling technique within the field of construction management include Akintoye et al. (1998), Oyedele (2013), Spillane et al. (2012), and Hodgson et al. (2011), among others.

A written invitation, explaining the purpose of the focus group discussions, were sent to the participants prior to the meetings. Each of the discussions was also commenced by the need for mapping out design strategies for waste mitigation as a means for mitigation economic and environmental impacts of waste generation. The discussions were moderated by two members of the research team, with each spanning between 75 and 90 minutes and recorded with permissions of the research participants. The voice data were then transcribed and read several times to identify core themes in the discussions, using content driven thematic analysis (Morse, 1994), which considers 
both implicit and explicit ideas emanating from the data (Braun and Clarke, 2006). The analytical technique follow a general phenomenological approach where data from the questions analysis are evaluated to identify significant statements and sentences that provides understanding of how participants experienced the phenomenon (Creswell, 2013). This analytical technique is also known as horizonalization (Moustakas, 1994), which is followed by careful development of clusters of meaning. As a result of yearning to uncover complex phenomenon, which may be hidden in large and unstructured data obtained from the discussions, Atlas-ti qualitative data analysis tool was employed. Overall, analytical processes involves data familiarisation within an Atlas-ti Hermeneutic Unit, generation of codes, search for themes, review and re-definition of themes as suggested by Braun and Clarke (2006).

\section{Data Analysis and Finding}

This section covers qualitative data analysis and findings from the study. The first part explains the process of data analysis, while the second part presents the result from data analysis

\subsection{Coding Scheme and Categorization}

In line with the procedure for thematic analysis, coding scheme and final categorization of identified factors were based on dominant themes that emerged from the interview script ( $R)$. The coding scheme enhanced identification of key strategies suggested by the respondents as well as the broad categories of measures for designing out waste. Word cruncher facility of Atlas-ti was used to facilitate initial data familiarization in order to carry out data driven thematic analysis.

In line with a study by $\mathrm{Gu}$ and London (2010), data coding was facilitated by the use of three categories of labelling. In addition to the identified comment from transcribed data, the three elements are code/super codes, discussions and strategies. Based on initial word crunching, codes were used to search through each of the four transcripts of focus group discussions. The discussion represents the focus group discussion from which a comment was made, while measures are the summed up statement and strategy derived from each comment. Table 2 demonstrates how some of the strategies were derived from thematic analysis. 
After identifying a number of strategies, similar factors were combined together to develop a robust measures for designing out waste. Based on this process, nine measures for designing out waste were established.

Table 2: Examples of coding data segments

\begin{tabular}{|c|c|l|l|}
\hline $\begin{array}{c}\text { Code/super } \\
\text { codes }\end{array}$ & Discussions & $\begin{array}{l}\text { Comments(from the data, highlighted by the code) } \\
\text { Complex(ity) }\end{array} \quad$ FG3 & $\begin{array}{l}\text { Measures (established } \\
\text { from the comment) }\end{array}$ \\
\hline Teconstruction & FG2 & $\begin{array}{l}\text { You sometimes have complex design, which is } \\
\text { understandable...however, detailing are more or } \\
\text { less the same regardless of complexity of design. } \\
\text { This usually led to errors, reworks and waste } \\
\text { generation. }\end{array}$ & $\begin{array}{l}\text { Complex designs are } \\
\text { adequately detailed to } \\
\text { prevent confusion }\end{array}$ \\
\hline Standard & FG1 & $\begin{array}{l}\text {..Largest proportion of landfill waste is generated } \\
\text { by demolition activities... Design could be used } \\
\text { to facilitate end of life waste minimization. For } \\
\text { instance, deconstruction plan could be produced } \\
\text { along with construction plan. }\end{array}$ & $\begin{array}{l}\text { Deconstruction plan as a } \\
\text { major element in the } \\
\text { design documents }\end{array}$ \\
\hline collaborate & FG4 & $\begin{array}{l}\text { A good way of using design to drive waste } \\
\text { minimization is by ensuring that the sizing of } \\
\text { spaces considers standard materials supplies....it } \\
\text { will minimize offcuts. }\end{array}$ & $\begin{array}{l}\text { Coordinate dimensions of } \\
\text { building elements based on } \\
\text { standard material size }\end{array}$ \\
\hline
\end{tabular}

\subsection{Findings}

This section aggregates and presents findings from the four focus group discussions with the industry's experts. The identified waste efficient design attributes were grouped under five different categories. These are (i) standardization and dimensional coordination (ii) design for modern methods of construction (iii) flexibility and adaptability (iv) end of life consideration (v) BIM coordination. The experts posit that by possessing the itemised features, design will support waste minimization/prevention during construction activities. Similarly, it was raised that by addressing a set of measures with respects to design documents, construction waste would be minimized. The attributes that are capable of enhancing waste efficiency of design documents are (i) completeness and clarity, (ii) Certainty and timeliness, (iii) error-free and, (iv) inclusion of waste scenario plans. Table 3 presents findings from the focus group discussions based on above categories. 
Table 3: Attributes of waste efficient designs and design documents

\begin{tabular}{|c|c|c|c|c|c|}
\hline \multirow{2}{*}{ Key features } & \multirow{2}{*}{ Waste effective attributes of design and design documents } & \multicolumn{4}{|c|}{ Focus Groups } \\
\hline & & 1 & 2 & 3 & 4 \\
\hline \multirow{9}{*}{$\begin{array}{c}\text { Design for } \\
\text { Standardization and } \\
\text { dimensional } \\
\text { coordination }\end{array}$} & 1. Detailing of the building elements are simple and clear for site use & & $\checkmark$ & $\checkmark$ & $\checkmark$ \\
\hline & 2. Complex designs are adequately detailed to prevent confusion & & & $\checkmark$ & $\checkmark$ \\
\hline & 3. $\quad$ Building forms and layout are standardized & & $\checkmark$ & $\checkmark$ & \\
\hline & 4. Drawings considers and integrate site topography and existing utilities & & $\checkmark$ & $\checkmark$ & \\
\hline & 5. Coordinate dimensions of building elements based on standard material size & $\checkmark$ & $\checkmark$ & $\checkmark$ & $\checkmark$ \\
\hline & 6. Tiles layout is optimized in conformity with design shape & & $\checkmark$ & $\checkmark$ & \\
\hline & 7. Specify full height door or door with fanlight to avoid cutting & $\checkmark$ & & $\checkmark$ & $\checkmark$ \\
\hline & 8. Standardize doors, windows and glazing areas based on size of fittings & $\checkmark$ & $\checkmark$ & $\checkmark$ & $\checkmark$ \\
\hline & 9. Avoidance of overly complex design, where possible, to avoid offcuts & & & $\checkmark$ & \\
\hline \multirow{5}{*}{$\begin{array}{c}\text { Design for modern } \\
\text { methods of construction }\end{array}$} & 10. Specification of structural prefabricated materials & $\checkmark$ & & $\checkmark$ & $\checkmark$ \\
\hline & 11. Modular coordination of building elements & & $\checkmark$ & & \\
\hline & 12. Design for preassembled components such as bathroom \& kitchen pods & $\checkmark$ & $\checkmark$ & & $\checkmark$ \\
\hline & 13. Specify the use of efficient framing techniques & & & $\checkmark$ & \\
\hline & 14. Employ volumetric modular design principles & $\checkmark$ & $\checkmark$ & & $\checkmark$ \\
\hline \multirow{3}{*}{$\begin{array}{c}\text { Design for flexibility } \\
\text { and adaptability }\end{array}$} & 15. Design for standard dimensions \& units to ensure reusability of the spaces & $\checkmark$ & $\checkmark$ & & $\checkmark$ \\
\hline & 16. Specify durable materials to avoid need for early replacement & & $\checkmark$ & & $\checkmark$ \\
\hline & 17. Design for changes and flexibility through collapsible partition & $\checkmark$ & $\checkmark$ & $\checkmark$ & $\checkmark$ \\
\hline \multirow{3}{*}{ Design for end of life } & 18. Produce disassembly and deconstruction plan of the building & & $\checkmark$ & $\checkmark$ & \\
\hline & 19. Specify the use of joint system instead of the usual gluing and nailing & $\checkmark$ & $\checkmark$ & $\checkmark$ & \\
\hline & 20. Specify the use of modular system that support disassembly & $\checkmark$ & $\checkmark$ & $\checkmark$ & $\checkmark$ \\
\hline \multirow{4}{*}{ BIM Coordination } & 21. Techniques in BIM and IPD are employed for design coordination & $\checkmark$ & & $\checkmark$ & \\
\hline & 22. Adequate information is provided through collaborative BIM platform & & & $\checkmark$ & $\checkmark$ \\
\hline & 23. Clash that could lead to reworks is designed out through collaboration & $\checkmark$ & $\checkmark$ & $\checkmark$ & $\checkmark$ \\
\hline & 24. As built end of life deconstruction guide is supplied in BIM model & & $\checkmark$ & $\checkmark$ & $\checkmark$ \\
\hline \multirow{4}{*}{$\begin{array}{l}\text { Completeness and } \\
\text { Clarity }\end{array}$} & 25. Design documents provide all required information & & $\sqrt{ }$ & & $\checkmark$ \\
\hline & 26. Design documents are legible and easily read/interpreted by all parties & & $\checkmark$ & $\checkmark$ & $\checkmark$ \\
\hline & 27. Design documents incorporate site conditions and topographical information & $\checkmark$ & & $\checkmark$ & \\
\hline & 28. Design documents employs conventional language understandable by all & $\checkmark$ & $\checkmark$ & $\checkmark$ & $\checkmark$ \\
\hline \multirow{2}{*}{$\begin{array}{c}\text { Certainty and timeliness } \\
\text { of design document }\end{array}$} & 29. No change or amendment is required of the design documents & $\checkmark$ & $\checkmark$ & $\checkmark$ & \\
\hline & 30. Documents are supplied as at when required to prevent delay\& make-do & & & $\checkmark$ & \\
\hline \multirow{3}{*}{$\begin{array}{c}\text { Error free } \\
\text { documentation }\end{array}$} & 31. Drawing documents are free of errors that could lead to reworks & & $\checkmark$ & $\checkmark$ & $\checkmark$ \\
\hline & 32. Specifications are detailed and devoid of under/over ordering & $\checkmark$ & & & $\checkmark$ \\
\hline & 33. Design from all trades are adequately coordinated to prevent clash & $\checkmark$ & & $\checkmark$ & $\checkmark$ \\
\hline \multirow{2}{*}{ Waste scenario plan } & 34. Waste management plan is prepared along with design & & $\checkmark$ & & \\
\hline & 35. Deconstruction plan as a major element in the design documents & & $\checkmark$ & $\checkmark$ & \\
\hline
\end{tabular}




\section{Case Study of a Renewable Energy Project}

A case study of a renewable energy facility was used to evaluate significance of identified strategies for designing out waste. The facility was designed to manage residual waste by generating energy from the waste, which could have ordinarily ended up in landfill. The motivation behind the project is prevention of negative environmental effects associated with waste landfilling, including generation of greenhouse gases that contributes to climate change. Apart from prevention of greenhouse gases, the energy from waste project helps in generating heat and electricity energy, thereby converting waste into energy. Table 4 summarises key features of the project.

Table 4: Key Features of the case study project

\begin{tabular}{|l|l|}
\hline Features & \multicolumn{1}{|c|}{ Project specification } \\
\hline Project & Construction of energy to waste facility \\
\hline Cost & Approximately $£ 50,000,000$ \\
\hline Location & England, UK \\
\hline Duration & 2 years \\
\hline Procurement route & PFI/PPP \\
\hline
\end{tabular}

The waste from energy project is a type of incineration involving burning of waste at higher temperature to generate electricity and for heating, usually by turning steam turbine. Materials that failed to burn at its usual temperature of about $850^{\circ} \mathrm{C}$, such as glasses, are collected at the bottom of its chamber and they are referred to as bottom ash. In addition to generation of heat and electricity for consumption, energy from waste facility was also designed to generate fly ash, which replaces proportion of cement in concrete.

As the project was designed to mitigate environmental impacts of waste generation, construction waste minimization was set as a key performance indicator for the project. Based on this, the project team adopted the confirmed strategy as a means of driving waste minimization in the waste to energy project. Waste output of the project in comparison with similar projects is suggests that implementation of the identified strategies could substantially drive waste minimization in construction projects. Using the UK BRE's SMARTWaste system, average waste generated per $£ 100,000$ of project cost is 14.7 tonnes for industrial buildings (WRAP, 2011). However, through implementation of strategies reported in this study, the waste-to-energy project generated approximately 5.7 tonnes of waste per $£ 100,000$ 
spent on the project. This represents a high level of waste efficiency that is driven by holistic approach for designing out waste. The finding confirms claims by Innes (2004) who argued that design strategy is capable of reducing waste by up to $33 \%$.

\section{Discussions}

As presented in table 3, a number of design strategies are requisite to achieving low waste construction projects. These sets of strategies are discussed in this section.

\subsection{Design for Standardization and Dimensional Coordination}

Coordination of design dimensions and specification of standard materials would not only improve constructability of buildings, it would also help in preventing avoidable off-cuts, which could lead to waste. Constructability of a building is a key factor that measures the extent to which efficient construction is factored into design and design processes (Mbamali et al., 2005). It has been reasoned that design teams are expected to take a leading role in ensuring buildability and constructability of their projects (Lam et al., 2006). Improved buildability of a design is not only required for early project completion and resource efficiency (Lovell, 2012), it is a proven way through which construction waste could be reduced (Yeheyis et al., 2013; Yuan, 2013b). Architects and design managers stress that:

"By coordinating dimension of designs, it would be easy to specify standard materials readily available, while little off-cutting, chiselling and other waste producing activities would be reduced".

On a similar note, Crawshaw (1976) suggests that a discrepancy of $10 \mathrm{~mm}$ in one dimension would not only affect contractors' programmes, it could cost up to $£ 3,000$ in reworks. As such, it is important that whilst error is prevented in dimension, design should also be standardized to avoid unnecessary offcuts. In a similar note, WRAP (2009) recommends standardization of building forms and layout and the use of full height doors as a means of reducing construction waste. This is in line with this study, which posits that apart from preventing errors in design, individual elements of the buildings are to be standardized based on market size of the materials. For instance, window and glazing area as well as door openings should be appropriately sized. A contractor stressed that: 
"You can imagine if 30mm gap has to be sizzled out of every door and window openings in a multi-storey building, this will result in huge volume of waste".

In line with this study, other authors have recommended dimensional coordination and standardization of building elements as an optimal means of reducing construction waste (Dainty and Brookes, 2004; Ekanayake and Ofori, 2004; Baldwin et al., 2007; Alshboul and Ghazaleh, 2014). It is expected that buildings are designed in response to site topography to avoid excavation waste (Yuan, 2013B), complex designs are adequately detailed to improve buildability (Negapan et al., 2013) and structural grid and planning grid are properly coordinated (WRAP, 2009). The respondents also stressed that:

"The use of standard elements and modular unit would not only reduce waste due to offcuts..., it would also ensure that building elements are readily reusable in other projects....this would therefore prevent demolition waste".

Thus, it is not only important that designers address dimensional coordination of the building elements, spaces and elements need to be standardized in design. This would result in reduction of both construction and end of life waste.

\subsection{Design for Modern Methods of Construction (MMC)}

MMC usually refers to building construction technique whereby buildings are factory manufactured and site assembled (Lovell, 2012). It involves a situation whereby various components of the building are manufactured in controlled factory environment and are transported to the site, where the components are assembly. On the other hand, innovative onsite building technologies are also sometimes referred to as MMC (Nawi et al., 2014).

The respondents believed that designing for MMC have a great tendency of reducing waste generated by the industry. These measures include designing for modular construction, prefabrication and preassembled components as well as the use of modern low waste techniques such as dry wall partitions. A respondent asserts that: 
"By adopting modern method of construction and other low waste technologies, complexities that result in waste could be reduced".

Another respondent added that:

The so-called modern methods of construction could be more expensive. However, they are not only waste effective; they also speed up construction process.

This position is also buttressed by earlier studies, which posit that adoption of modern methods of construction, such as offsite construction and prefabrication of building components, significantly reduces construction waste (Cf. Dainty and Brooke, 2004; Al-Hajj and Hamani, 2011). For instance, Jaillon et al. (2009) suggests that construction waste could be reduced by up to $84.7 \%$ when prefabrication and modular technology is used. Tam et al. (2007) also claimed that waste output of a construction project could be reduced by $52 \%$ by specifying and using prefabrication system. All these suggest that apart from supporting constructability and deconstructability of buildings, prefabrication and modular technologies would assist in significant waste reduction (Formoso et al., 2002; Oyedele et al., 2013). It is therefore important that designers consider the MMC while designing, as the methods are proven waste efficient (Yuan, 2013; Kozlovska and Splsacova, 2013).

\subsection{Flexibility and Adaptability of design}

In order to reduce waste generated by the construction industry, designers' waste management measures should go beyond immediate construction activities and current use to which the building is put. It is important that buildings be designed for flexibility and change, in a way that building modification and change in spatial configuration will result in minimal waste. This is particularly necessary as evidence suggests that substantial proportion of waste generated by the construction industry is as a result of renovation works (Esin and Cosgun, 2007). In line with this, respondents argue that:

"If buildings are made responsive and easily adaptable to change, it would prevent demolition waste that could accrue from remodelling and modifications".

Similarly, McKechnie and Brown (2007) and Yuan (2013b) suggest that design should be made so flexible that future change in its spatial configuration would result in less 
modification, and subsequently less waste. Accordingly, the respondents suggest that specification of durable materials would as well reduce incessant replacement of building elements. Therefore, durability of the building materials, flexibility of building spaces, and deconstructability of the whole building at the end of its lifecycle should be well thought out by the designers (Ajayi et al., 2015). These would assist in reducing waste generated by construction and demolition activities.

\subsection{End of life consideration}

Despite the common knowledge that building demolition waste constitute a larger portion of total waste generated by the construction industry, less is being done to reduce the end of life waste. The reason for this oversight is not far-fetched. The respondents posit that:

"Since demolition might not occur until probably after 60years, most people see no reason why they should waste time preventing it. After all, they are not being paid for it, and it is not even part of design contract"

However, it was consensually agreed that by planning for deconstruction right from design stage, waste generated by the industry would be substantially reduced. Meanwhile, designing for deconstruction is recognised as one of the five spectrums through which waste could be designed out in construction projects (WRAP, 2009). It involves careful planning, designing and selection of building materials in such a way that the building would support selective demolition of the building elements (Saghafi and Teshnizi, 2011). Respondents argue that:

"Although the construction industry is waste intensive, the proportion generated by demolition activities is far higher than those generated by actual construction... It is important that we plan for deconstruction through design and construction activities"

"Designers could enhance deconstructability of buildings by specifying joint system instead of gluing or nailing.......it will also be helpful for demolition engineers if there is disassembly plan" 
It is therefore clear that careful planning for buildings to support deconstruction at the end of its lifecycle would reduce waste generated by the industry. This finding buttressed earlier studies by Oyedele et al. (2003) which suggests that in order to reduce landfill waste, there is need that deconstruction plan becomes part of design documentation. Thus, a major attribute of waste efficient design is the extent to which deconstruction has been factored into it.

\subsection{Use of BIM for design coordination}

Due to its fragmented and dynamic nature, construction activities usually involve series of errors capable of influencing project success. When error occurs, it leads to reworks, which in turns affect project cost and results into waste. Although cost of reworks has significantly reduced from 30\% around 1970s (Crawshaw, 1976), it still accounts for about 5\% of project costs (Hwang et al., 2012). Significant causes of construction error are incorrect or inadequate design document (Oluwaseun and Olumide, 2013), lack of dimensional coordination (Crawshaw, 1976), ineffective project communication and coordination, inconsistent procurement documentation, unclear allocation of responsibilities (Osmani, 2012), document delay (Koskela, 2004), and non-involvement of contractors in design decisions (Arain et al., 2004).

As the adoption of BIM is becoming commonplace within the construction industry, respondents posit that the use of BIM for design coordination is essential to reducing waste generated by construction activities. Respondents assert that:

By employing BIM for design coordination, design clash that usually lead to reworks and waste would be greatly reduced.

Most of the design-induced waste could be traced to inadequate information sharing among the project team. If we channel BIM properly, this could be well reduced.

As a technologically driven collaborative platform, Building Information Modelling is capable of enhancing digital representation, collaborative production, storage and sharing of 
building information. This ensures that building information are kept updated throughout its lifecycle, thereby enhancing end of life deconstruction and reusability of the building elements. Apart from its capacity to prevent immediate clash and ensure end of life deconstruction, the use of BIM would also enhance information sharing and early collaboration among project stakeholders, thereby foreseeing likely causes of waste (Ajayi et al., 2014). Similarly, as most error at construction stage is usually due to contractors' poor knowledge of the design and its documentation (Dainty and Brooke, 2004), the use of BIM would ensure early contractors' familiarization and contribution to design.

\subsection{Completeness and Clarity of design document}

Quality of design documents have great impacts on overall effectiveness of the build process (Andi and Minato, 2003; Gann et al., 2003). It also have tendency of influencing waste generated by construction activities. For instance, design errors and wrong detailing have tendency of resulting in construction errors, which will in turns lead to reworks (Faniran and Caban, 1998). As such, completeness and accuracy of design documents is important to reducing waste generated by construction activities. Strong indications emerged from focus group discussions that:

"Detailing of the design, accuracy and completeness of the whole design documents will surely affect the waste output of a project”.

This is because; design documents do not only affect buildability of the project, its comprehensiveness and accuracy would go a long way in preventing errors that could lead to reworks (Formoso et al., 2002). Civil/structural engineers and project managers posit that:

"One of the most common problem we encounter is when the design document failed to incorporate site conditions such as topography and other unique features".

Therefore, it is not only important that design documents provide adequate information, it is required that it employs conventional language and incorporate all features that are site 
specific. It is vital that design documents are legibly presented (Andi and Minato, 2003; Baldwin et al., 2007) in consistent detailing language and format, easily understood by all trades involved in the project lifecycle.

\subsection{Certainty and timeliness of design documents}

Design change is one of the major activities that contributes to waste intensiveness of the construction industry (Faniran and Caban, 1998; Ekanayake and Ofori, 2004). This is usually as a result of errors that requires amendment to the design, need to work within a realistic budget or as a result of owners' change in requirement. As such, a major feature of waste efficient design is that it incorporates adequate measures capable of preventing design change. This means that efforts should be made to ensure that design is made for the targeted budget and should be devoid of errors, which could otherwise require amendments. In order to avoid make-do waste, which is a result of late supply of essential design information (Koskela, 2004), it is expected that designs be supplied to time. A respondent posit that:

\footnotetext{
"What would you expect to happen if you are working on a site with inadequate design document? If we are truly committed to waste reduction, it means we should not start construction until we are sure that the design is complete and adequately detailed".
}

This would ensure that construction activities are carried out with a freeze design documents and adequate information, thereby preventing errors that could otherwise result into reworks and subsequent waste.

\subsection{Error free documentation}

Apart from architects, civil/structural engineers and design managers, other respondents also opined that error and ambiguity of design documentation is, arguably, a major cause of waste. This was similarly echoed by Osmani et al. (2008) who identify design error as one of the activities leading to reworks. It is expected that latest technology such as BIM is used in coordinating and integrating designs from all trades (e.g. M\&E, architecture, structure, etc.) 
to avoid clash and trade based errors and discrepancies (Domingo et al., 2009). One respondent submits that:

"With latest trends in BIM, I think we are moving closer to a stage where construction industry will generate less waste. If it is employed in coordinating designs from all parties, we would be able to sort out issues of design clash, which is a major cause of rework and waste".

Others opined that:

"Waste prevention should start from accuracy and clarity of design documents. It should be clear of errors... Specification and detailing should be clear and free from error... and the documents should be finished to time...."

Specification as an important document usually prepared as part of design process has a decisive influence on waste output of construction project. As echoed in the focus group discussions, if the issue of over-ordering, under-ordering and over-allowance were well addressed in schedule and specification document, less waste would be produced on construction sites. In similar studies, Begum et al. (2009), Oyedele et al. (2003) and Osmani (2013) considered inadequate specification as a major cause of waste in construction project. It is therefore important that design and specification documents be accurately prepared in order to prevent waste that could arise from deficiencies in design documentation.

\subsection{Inclusion of waste scenario plans}

Across all the focus group discussions, strong indication emerged that several design documents usually lack substantial information required for successful construction exercise, thereby leaving the contractors with guesswork and subsequent waste generation. It is expected that adequate design information be provided in the design document to ensure that subsequent businesses are carried out with less waste (Khanh and Kim, 2014). Current industry practices lack provision for preparation of deconstruction plan. However, the focus group discussants suggest that, like normal building plan, deconstruction plan is expected to become an integral part of design documentation. This was similarly echoed by Oyedele et al. (2013) who reasoned that design document remains waste inefficient until SWMP and 
deconstruction plans are prepared. As such, while conventional drawing documents are prepared with adequate information, inclusion of other documentations could enhance its waste effectiveness. In line with this study, bar bending list was suggested by Al-Hajj and Hamani (2011) as required parts of waste preventive design documents. As the documents would assist in guiding construction and deconstruction activities, it is clear that they have tendency of reducing waste generated by construction and demolition activities.

\section{Conclusion}

Despite the consensus that waste efficient design is important for reducing waste generated by construction and demolition activities, design strategies for actual waste mitigation remains unclear. In addition, decisive roles required of designers in designing out waste remains inadequately addressed. As such, this study employs phenomenology approach in determining attributes of waste effective design and design documents. The study suggests that for a design to assist in reducing construction and demolition waste, it needs to fulfil five key requisites, while its effective documentation requires four key requisites.

For a design to be deemed waste efficient, it is expected to incorporate principles of standardization and dimensional coordination by ensuring that sizing of spaces and building elements conform to available standard size of materials and site-specific features, thereby minimizing offcut. In addition, employment of the principles in modern methods of construction, provisions for end of life deconstruction and incorporation of measures for spatial and components flexibility in design would enhance buildability and deconstructability of the buildings, as well as reusability of its elements, thereby increasing its lifecycle waste efficiency. Coordination of the design through techniques in BIM would also help in preventing waste inducing occurrences such as design clash, inadequate information and poor collaboration. Apart from being error free, design documents are meant to be characterised by completeness and clarity, which defines its provision of adequate information, use of conventional detailing language/format and incorporation of site-specific conditions. While including plans and schedules that are potentially waste militating such as deconstruction plan, certainty of the documented design and its supply to time are essential features of waste efficient design documents. 
The study has implication for design practices as well as overall project planning and management. At the planning level, the study advocates a total shift from waste intensive techniques to waste effective construction strategies. This involves the use of such measures as prefabrication techniques, flexible design, pre-assembled components, as well as modular design principles, which are all proven waste effective strategies. Shifting towards these techniques would therefore enhance constructability and deconstructability of buildings, which are important for construction and demolition waste minimization. Being the main driver of the build process, designers should address overall aspects of constructability, deconstructability and reusability of the building elements right from design. By considering standard materials sizes in design, materials offcut as well as other waste intensive activities such as chiselling, cut-corners and so on would be reduced. With design documents being capable of influencing construction waste, careful attention needs to be given to accuracy and comprehensiveness of design documents. It is not only important that design documents are accurate and error free, it is expected to be characterised by completeness and clarity, certainty and timeliness and incorporation of set of plans and schedules that are waste militating.

As this study only involved an in-depth exploration of phenomenon with qualitative data, other studies employing quantitative data could widen the breadth of its findings and determine its generalizability. Transferability of the findings of this study to other nations than the UK, from where its data was collected, could as well be determined by further studies. Similarly, with this study identifying several design strategies, it is expected that further studies established key design strategies that are critical to designing out construction waste and prevention of waste inducing activities.

\section{Acknowledgement}

The authors would like to express their sincere gratitude to Innovate UK (formerly Technology Strategy Board - TSB) and Balfour Beatty PLC for providing financial support for the research (under "Rethinking the build process"), through application No: 22883158278 and file reference No: 101346. 


\section{References}

Ajayi, S.O., Oyedele, L.O., Akinade, O.O., Bilal, M., Owolabi, H.A., and Alaka, H.A. (2014). Ineffectiveness of construction waste management strategies: Knowledge gap analysis. In: Okeil, M. (2014). Smart, sustainable and healthy city, Proceedings of the First International Conference of the CIB Middle East and North Africa Research Network (CIB-MENA 2014), pp. 261 - 280.

Ajayi, S. O., Oyedele, L. O., Ceranic, B., Gallanagh, M., \& Kadiri, K. O. (2015). Life cycle environmental performance of material specification: a BIM-enhanced comparative assessment. International Journal of Sustainable Building Technology and Urban Development, 6(1), pp. 14-24.

Ajayi, S.O., Oyedele, L.O., Bilal, M., Akinade, O.O., Alaka H.A., Owolabi, H.A., and Kadiri, K.O. (2015a). Waste Effectiveness of the Construction Industry: Understanding the Impediments and Requisites for Improvements. Resources, Conservation and Recycling

Akintoye, A., Taylor, C., \& Fitzgerald, E. (1998). Risk analysis and management of private finance initiative projects. Engineering, Construction and Architectural Management, 5(1), pp. 9-21.

Al-Hajj, A., \& Hamani, K. (2011) Material Waste in the UAE Construction Industry: Main Causes and Minimization Practices. Architectural Engineering and Design Management, 7(4), pp. $221-235$.

Alshboul, A. A., \& Ghazaleh, S.A. (2014). Consequences of Design Decisions on Material Waste during Construction Survey of Architects' Point of View, the Case of Jordan. Jordan Journal of Civil Engineering, 8(4), pp. 363 - 374

Anderson, J., Shiers, D., \& Sinclair, M. (2002). The Green Guide to Specification, 3rd edition. Oxford: Blackwell publishing.

Andi \& Minato, T. (2003). Design documents quality in the Japanese construction industry: factors influencing and impacts on construction process. International Journal of Project Management, 21(7), pp. 537-546.

Arain, F. M., Assaf, S., \& Pheng, L. S. (2004). Causes of discrepancies between design and construction. Architectural Science Review, 47(3), 237-249.

Baldwin, A., Poon, C., Shen, L, Austin, S., \& Wong, I. (2007). Reducing construction waste by decision within the design process. In proceeding: CIB World Building Congress, 2007 , pp. $2568-2583$. 
Begum, R. A., Siwar, C., Pereira, J. J., \& Jaafar, A. H. (2007). Implementation of waste management and minimisation in the construction industry of Malaysia. Resources, Conservation and Recycling, 51(1), pp. 190-202.

Begum, R.A., Siwar, C., Pereira, J. J., \& Jaafar, A.H. (2009). Attitude and behavioural factors in waste management in the construction industry of Malaysia. Resources, Conservation, and Recycling, 53(6), pp. 321-328.

Benjamin, D.K. (2010). "Recycling Myths Revisited". PERC Policy series 47, Montana: Property and Environmental Research Centre (PERC).

Braun, V., \& Clarke, V. (2006). Using thematic analysis in psychology. Qualitative research in psychology, 3(2), pp. 77-101.

BRE, (2003). Construction and demolition waste: Good buildings guide 57 Part 1. UK: Building Research Establishment

Cha, H. S., Kim, J., \& Han, J. Y. (2009). Identifying and assessing influence factors on improving waste management performance for building construction projects. Journal of construction engineering and management, 135(7), pp. 647-656.

Chong, W.K., \& Hermreck, C. (2011). Modeling the use of transportation energy for recycling construction steel. Clean Technology and Environmental Policy, 13(2), pp. 317-330.

Coventry, S., \& Guthrie, P. (1998). Waste minimization and recycling in construction: design manual. London: CIRIA.

Crawshaw, D. T. (1976). Coordinating working drawings. UK: Building Research Establishment, Department of the Environment.

Creswell, J. (1998). Qualitative Inquiry and Research Design: Choosing Among Five Traditions. London: Sage Publications.

Creswell, J. W. (2013). Qualitative inquiry and research design: Choosing among five approaches, $3^{\text {rd }}$ edition. Thousand Oaks: Sage.

Crotty, M. (1998). The foundations of social research: Meaning and perspective in the research process. London: Sage Publications

Dainty, A.R.J., \& Brooke, R.J. (2004). Towards improved construction waste minimisation: a need for improved supply chain integration? Structural Survey, 22(1), pp. 20-29.

Department for Environment, Food and Rural Affairs (Defra, 2013). Waste Prevention Programme for England: Overview of Evidence - A rationale for waste prevention in England. London: Defra. 
Domingo, N., Osmani, M., \& Price, A. D. (2009). Construction waste minimisation in the UK healthcare industry. In: Dainty, R.J. (Ed.). Proceedings of the 25th Annual ARCOM Conference, 7-9 September 2009, Albert Hall, Nottingham. Association of Researchers in Construction Management, Vol. 2, pp. 1021-30.

Ekanayake, L. L., \& Ofori, G. (2004). Building waste assessment score: design-based tool. Building and Environment, 39(7), pp. 851-861.

Esin, T., \& Cosgun, N. (2007). A study conducted to reduce construction waste generation in Turkey. Building and Environment, 42(4), pp. 1667-1674.

Faniran O. O., \& Caban G. (1998). Minimizing waste on construction project sites. Enginnering, Construction and Architectural Management, 5(2), pp. 182-188.

Formoso, C. T., Soibelman, L., De Cesare, C., \& Isatto, E.L. (2002). Material Waste in Building Industry: Main Causes and Prevention. Journal of Construction Engineering and Management, 128(4), pp. 316 - 325.

Gann, D., Salter, A., \& Whyte, J. (2003). Design quality indicator as a tool for thinking. Building Research and Information, 31(5), pp. 318-333.

Global Construction (GC, 2013). "A global forecast for construction-2025" [online]. Available through: http://www.globalconstruction2025.com/. [Accessed: 16th July, 2014].

HM Government (2008). Strategy for sustainable construction. London: Department for Business, Enterprise and Regulatory Reform

Hodgson, D., Paton, S., \& Cicmil, S. (2011). Great expectations and hard times: The paradoxical experience of the engineer as project manager. International Journal of Project Management, 29(4), pp. 374-382.

Holloway, I., \& Wheeler, S. (1996). Qualitative research for nurses. Oxford: Blackwell Science.

Hwang, B. G., Thomas, S. R., Haas, C. T., \& Caldas, C. H. (2009). Measuring the impact of rework on construction cost performance. Journal of Construction Engineering and Management, 135(3), 187-198.

Innes, S. (2004). Developing tools for designing out waste pre-site and onsite. In: Proceedings of Minimising Construction Waste Conference: Developing Resource Efficiency and Waste Minimisation in Design and Construction, New Civil Engineer, London, UK, October 2004. 
Jaillon, L., Poon, C. S., \& Chiang, Y. H. (2009). Quantifying the waste reduction potential of using prefabrication in building construction in Hong Kong, Waste management, 29(1), pp. 309-320

Jasper, M.A. (1994). Issues in phenomenology for researchers of nursing. Journal of Advanced Nursing, 19 (1994), pp. 309-314

Khanh, H. D., \& Kim, S.Y. (2014). Identifying Causes for Waste Factors in High-Rise Building Projects: A Survey in Vietnam. KSCE Journal of Civil Engineering, 18(4), pp. 865-874

Koskela, L. J. (2004, August). Making do-the eighth category of waste. In: Proceedings of the 12th annual conference of the International Group for Lean Construction, 3-5 August 2004, Helsingor, Denmark.

Kozlovska, M., \& Splsacova, M. (2013). Construction waste generation across construction product life cycle. International Journal on Organization, Technology and Management in Construction 5(1), pp. 687 - 695

Kvale, S. (1996). InterViews: An Introduction to Qualitative Research Interviewing. Thousand Oaks California: Sage Publications

Lam, P. T., Wong, F. W., \& Chan, A. P. (2006). Contributions of designers to improving buildability and constructability. Design Studies, 27(4), pp. 457-479.

Lau, H.H., Whyte, A., \& Law, P.L. (2008). Composition and characteristics of construction waste generated by residential housing project. International Journal of Environmental Research 2(3), pp. 261-268.

Love, P. E., Edwards, D. J., \& Irani, Z. (2008). Forensic project management: An exploratory examination of the causal behavior of design-induced rework. Engineering Management, IEEE Transactions on, 55(2), 234-247.

Lovell, H. (2012). Modern Methods of Construction, In: Smith, S.J. (ed.) The Elsevier International Encyclopedia of Housing and Home, vol.4, pp. 312-316.

Mbamali, I., Aiyetan, O. A., \& Kehinde, J. O. (2005). Building design for buildability: an investigation of the current practice in Nigeria. Building and environment, 40(9), pp. 1267-1274.

McKechnie, E., \& Brown, E. (2009). Achieving effective waste minimisation through design: Guidance on designing out waste for construction clients, design teams and contractors. Oxon: Waste and Resource Action Plan. 
Merriam, S. B. (1998). Qualitative research and case study applications in education. Revised and expanded from case study research in education. San Francisco, CA: Jossey-Bass Publishers

Morse, J. M. (ed.) (1994). Critical issues in qualitative research. Thousand Oaks: Sage

Moustakas, C. (1994). Phenomenological research methods. Thousand Oaks: Sage Publications.

Nagapan, S., Rahman, I.A., Asmi, A., Memon, A.H., \& Zin, R.M. (2012). Identifying Causes of Construction Waste - Case of Central Region of Peninsula Malaysia. International Journal of Integrated Engineering, 4(2), pp. 22-28

Nawi, M.N.M., Abu Hanifa, F.A., Kamar, K.A.M., Lee, A., \& Azman, M.N.A. (2014). Modern Method of Construction: An Experience from UK Construction Industry. Australian Journal of Basic and Applied Sciences, 8(5), pp. 527-532.

Oluwaseun S. D., \& Olumide A. A. (2013). Causes, effects and remedies of errors in Nigerian construction documents. Organization, Technology \& Management in Construction: An International Journal, 5(1), 676-686.

Osmani, M. (2012). Construction Waste Minimization in the UK: Current Pressures for Change and Approaches. Procedia - Social and Behavioral Sciences, 40 (2012), pp. $37-40$.

Osmani, M. (2013). Design waste mapping: A project life cycle approach. Proceedings of the ICE-Waste and Resource Management, 166(3), pp. 114-127.

Osmani, M., Glass, J., \& Price, A.D.F. (2008). Architects' perspectives on construction waste reduction by design. Waste Management, 28(7), pp. 1147-1158.

Oyedele, L. O., Ajayi, S. O., \& Kadiri, K. O. (2014). Use of recycled products in UK construction industry: An empirical investigation into critical impediments and strategies for improvement. Resources, Conservation and Recycling, 93(2014), pp.2331.

Oyedele, L., Jaiyeoba, B., \& Fadeyi, M. (2003). Design Factors Influencing Quality of Building Projects in Nigeria: Consultants' Perception. Australasian Journal of Construction Economics and Building, 3(2), pp. 25-32.

Oyedele, L.O., Regan, M., Meding, J.V., Ahmed, A., Ebohon, O.J., \& Elnokaly, A. (2013). Reducing waste to landfill in the UK: identifying impediments and critical solutions. World Journal of Science, Technology and Sustainable Development, 10(2), pp. 131 142. 
Oyedele, L. O., \& Tham, K. W. (2007). Clients' assessment of architects' performance in building delivery process: Evidence from Nigeria. Building and Environment, 42(5), 2090-2099.

Paine, K. A., \& Dhir, R. K. (2010). Recycled aggregates in concrete: a performance related approach. Magazine of Concrete Research, 62 (7), pp. 519 - 530.

Polkinghorne, D. E. (1989). Phenomenological research methods. In: Hailing, S., \& Valle, R. (1989). Existential-phenomenological perspectives in psychology, pp. 41-60. New York: Springer.

Poon, C.S. (2007). Reducing construction waste. Waste Management, 27(2007), pp. 17151716.

Saghafi, M. D., \& Teshnizi, Z. A. H. (2011) Building deconstruction and material recovery in Iran: an analysis of major determinants. Procedia Engineering, 21(2011), pp. 853-863.

Saraiva, T.S., Borges, M.M, \& Filho, A.C. (2012). "The Importance of Recycling of Construction and Demolition Waste". In Proceeding: 28th Conference, Opportunities, Limits \& Needs towards an environmentally responsible architecture Lima, Perú 7-9 November 2012.

Spillane, J. P., Oyedele, L. O., \& von Meding, J. (2012). Confined site construction: An empirical analysis of factors impacting health and safety management. Journal of Engineering, Design and Technology, 10(3), pp. 397-420.

Sterman, J.D. (1992). "System dynamic Modelling for Project Management," Sloan School of Management, MIT (online). Available at: http://web.mit.edu/jsterman/www/SDG/project.pdf. [Accessed: May, 2014]

Tam, C.M., Tam, V.W.Y., Chan, J.K.W., \& Ng, W.C.Y. (2005). Use of Prefabrication to Minimize Construction Waste - A Case Study Approach. The International Journal of Construction Management, 5(1), pp. 91-101.

Tam, V.W.Y., Tam, C.M., Zeng, S.X., Ng, C.Y. (2007). Towards adoption of prefabrication in construction. Building and Environment, 42(10), pp. 3642-3654.

Thomas, S. R., Lee, S. H., Spencer, J. D., Tucker, R. L., \& Chapman, R. E. (2004). Impacts of design/information technology on project outcomes. Journal of Construction Engineering and Management, 130(4), 586-597.

Treolar, G.J., Gupta, H., Love, P.E.D., \& Nguyen, B. (2003). An analysis of factors influencing waste minimisation and use of recycled materials for the construction of residential buildings. Management of Environmental Quality: An International Journal, 14 (1), pp. 134-145. 
Tribelsky, E., \& Sacks, R. (2011). An empirical study of information flows in multidisciplinary civil engineering design teams using lean measures. Architectural Engineering and Design Management, 7(2), 85-101.

Van Manen M. (1990). Researching lived experience: Human science for an action sensitive pedagogy. London, Ontario: Althouse.

Udawatta, N., Zuo, J., Chiveralls, K., \& Zillante, G. (2015). Improving waste management in construction projects: An Australian study. Resources, Conservation and Recycling, 101 (2015), pp. 73-83.

Wang, J., Li, Z., \& Tam, V.W.Y. (2014). Critical factors in effective construction waste minimization at the design stage: A Shenzhen case study, China. Resources, Conservation and Recycling, 82(2014), pp. 1-7.

Wimpenny, P., and Gass, J. (2000). Interviewing in phenomenology and grounded theory: Is there a difference? Journal of Advanced Nursing, 31(6), pp. 1485-1492.

WRAP (2009). Designing out waste: A design team guide for buildings (online). Available at: http://www.modular.org/marketing/documents/DesigningoutWaste.pdf. [Accessed: March, 2014]

WRAP (2011). How benchmark data can be used by contractors (online). Available at: http://www.wrap.org.uk/sites/files/wrap/CRWPLeafletContractors.pdf. [Accessed: March, 2014]

Yeheyis, M., Hewage, K., Alam, M.S., Eskicioglu, C., \& Sadiq, R. (2013). An overview of construction and demolition waste management in Canada: A lifecycle analysis approach to sustainability. Clean Technologies and Environmental Policy, 15(1), pp. 81 $-91$.

Yuan, H. (2013). Key indicators for assessing the effectiveness of waste management in construction projects. Ecological Indicators, 24(2013), pp. 476-484.

Yuan, H. (2013b). Critical management measures contributing to construction waste management: Evidence from construction projects in China. Project Management Journal, 44(4), pp. 101-112. 